\title{
A Far Away and Nameless State: The Travel Narratives of Frieda \\ Lawrence and Caitlin Thomas
}

\author{
KATHERINE COLLINS
}

\begin{abstract}
Not I But the Wind... and Leftover Life to Kill, the somewhat obscure mid-twentieth-century memoirs by Frieda Lawrence and Caitlin Thomas, were written, at least in part, in the countries that the authors eventually made their permanent home: New Mexico and Italy, respectively. While neither was marketed as a 'travel book', both works share many of the characteristics identified in the critical literature on women's travel writing, such as the way the memoirs were received as emotional outpourings with little authority outside the personal sphere and little of interest aside from their intimate knowledge of the authors' respective literary spouses. The analysis presented in this article shows that while Frieda and Caitlin sought to escape the gendered and classed strictures that so oppressed them in England, they applied them nevertheless to the individuals they encountered on their travels. Turning to the issue of viewpoints and watching, the article explores the frequency with which both narrators chose to position themselves behind windows as they set their scenes, indicating a more complex interrelation between watcher and watched than might first be assumed.
\end{abstract}

Keywords: Frieda Lawrence; Caitlin Thomas; women's travel writing, memoir, viewpoint, gaze 
The eyes of others our prisons; their thoughts our cages.

Virginia Woolf, 'An Unwritten Novel'

Frieda Lawrence (née Emma Maria Frieda Johanna Freiin (Baroness) von Richthofen, 18791956) and Caitlin Thomas (née Macnamara, 1913-1994) ${ }^{1}$ were born 34 years apart in different countries. However, there are a number of commonalities to their lives beyond their marriage to noted modernist writers which make a comparative analysis of their memoirs Frieda's Not I But the Wind... (1934) and Caitlin's Leftover Life to Kill (1957) - productive. There are several similar themes in their family backgrounds, not least their lifelong experiences of transnationality, understood here as the 'mobility, confusion, [and] sheer messiness of ordinary lives' which 'threatens the stability of national identity'. ${ }^{2}$

Caitlin's and Frieda's lives can be understood as transnational not just because they travelled and lived in different countries, but also as a consequence of their lived experience of transnational identities, beginning in childhood. The daughter of German Baron Friedrich Ernst Emil Ludwig von Richthofen and Frenchwoman Anna Elise Lydia Marquier, Frieda was born in Metz, now a city in France but at the time of her birth within the German Imperial Territory of Alsace-Lorraine and subject to a regime of Germanization. The occupation made Frieda uneasy; according to one of her biographers, Frieda felt that she 'ought to be like [the locals] but wasn't'. ${ }^{3}$ Caitlin was born in Hammersmith, the daughter of poet Francis Macnamara, of an Irish Protestant landowning family, and Mary (Yvonne) Majolier, whose father was a French Quaker. ${ }^{4}$ Caitlin's was an unconventional childhood 
with almost no formal education; her first three years were spent between family homes in London and County Clare in Ireland. ${ }^{5}$

Both women also had complex relationships with their fathers. After Francis Macnamara left his young family to pursue his artistic and political ambitions, Caitlin's mother and two sisters spent time living in the rambling, bohemian household of the painter Augustus John and Dorelia McNeil. ${ }^{6}$ Frieda's father was similarly unreliable: a gambler who struggled to pay his bills and was unfaithful to his wife. ${ }^{7}$ Both women wanted more from life than the traditional path of marriage and motherhood. Caitlin was convinced of her artistic talents, sure that she would achieve the success - as a painter, dancer, or poet - that had thus far eluded her father. At sixteen, she and Augustus John's daughter, Vivien, ran away to London to become dancers. Caitlin spent a year dancing in Paris before returning to London where, at the age of 21, she met the Welsh poet Dylan Thomas (1914-1953), whom she married in 1937. Frieda, at the age of 20, married British academic Ernest Weekley in 1899, moved to Nottingham, and had three children. During this time Frieda edited, and in some cases translated from German to English, works of writers such as Ludwig Bechstein and Friedrich Schiller for Blackie's Little German Classics, ${ }^{8}$ and translated to German, with E. L. Stahl, W. B. Yeats's play The Land of Heart's Desire. ${ }^{9}$

Thirteen years after getting married to Weekley, dissatisfied with domestic life, Frieda met D. H. Lawrence (1885-1930), a former student of her husband, and shortly afterwards they eloped to Germany, leaving her children with their father in England. They spent time with Frieda's family in Metz before the couple walked across the Alps into Italy. In 1913 they returned to England and Frieda made an unsuccessful attempt to see her children. Following Frieda's divorce, the couple were married in a private ceremony in July 1914, and were obliged to stay in England during World War I. They experienced several difficulties during this period, related in part to Frieda's nationality, to which I will return in a later section. 
From 1918 the Lawrences travelled widely, settling in New Mexico for a period before returning to Europe and living in Tuscany and southern France until D. H. Lawrence's death in 1930, shortly after which Frieda returned to New Mexico.

Like Frieda, Caitlin bitterly resented the stifling effect of marriage and motherhood on her creativity and, no longer dancing professionally, she wrote when she could, starting an autobiography during the Second World War. This work was never published, nor were any of the poems she continued to write throughout her marriage. ${ }^{10}$ After her husband's death in 1953, Caitlin spent several months on Elba. After returning briefly to Wales, she travelled to Naples and Procida before settling, with her Sicilian partner, in Rome from $1957 .{ }^{11}$

Both the Lawrence and Thomas marriages were tempestuous, with infidelity, it seems, on both sides. Both women saw their spouses as geniuses and had a complicated relationship, in several respects, with the attention their famous husbands attracted from critics and admirers, especially other women. The next section introduces Not I But the Wind... and Leftover Life to Kill in more detail and summarises their critical reception at the time of publication.

\section{THE TEXTS AND THEIR RECEPTION}

Not I But the Wind... was published by The Viking Press in 1934 and later republished as part of Rosie Jackson's 1994 biography of Frieda Lawrence. It is a retrospective account, written in the first person, of the portion of Frieda's life spent with D. H. Lawrence, beginning with their first meeting in 1912 and concluding with his death in 1930. During this period the Lawrences travelled extensively in Europe, including England, France, Germany, and Italy; they also travelled further afield to Ceylon, Australia, Tahiti and the US. The book proceeds chronologically, with the occasional and brief foray into Frieda's authorial present in Taos, New Mexico. It includes some photographs, as well as letters and poems by D. H. Lawrence, 
selected by Frieda. Her prose is lean and sparse and her chapter headings descriptive of the contents, such as 'We meet' and 'Walking to Italy'.

Leftover Life to Kill, published in 1957 by Putnam in the UK and Little, Brown \& Co. in the US, was Caitlin's first publication, though she had written an autobiography during the Second World War and wrote poetry throughout her marriage. ${ }^{12}$ This book is also a memoir written in the first person but with two quite distinct temporalities. The first covers Caitlin's six months on the island of Elba, ${ }^{13}$ where she drafted at least some portions of the book. Woven through this chronological account of her immediate past is the second temporality, Caitlin's recollections of Dylan's death, their marriage, and a few snippets of her adolescence. This book contains no photographs and nothing of Dylan's writing except the symbolic epigraph 'I make this in warring absence'; ${ }^{14}$ according to a later memoir, this poem was written for Caitlin shortly after their marriage. ${ }^{15}$ At the time she wrote it, Caitlin intended Leftover to be a literary work. ${ }^{16}$ Her prose is packed with figurative language, some of which is skilful and surprising, but the general effect is of over-writing, with image stacked upon image in rambling sentences.

In the circumstances - the death of a controversial literary celebrity at a relatively young age - it is not surprising that both Caitlin's and Frieda's books were received in context of other contemporaneously published accounts by other members of those writers' inner circles. In Frieda's case, her book was called the 'completion of the triangle', ${ }^{17}$ as it was the third account to be published a woman close to D.H. Lawrence in the later years of his life. The other two accounts were written by Mabel Dodge Luhan (1879-1962), a writer and patron of the arts; and artist and socialite Dorothy Brett (1883-1977). There were ongoing tensions between the three women - Frieda, Mabel and Dorothy - including a supposed plot to steal D. H. Lawrence's ashes from Frieda. ${ }^{18}$ Dodge Luhan's Lorenzo in Taos (1932), a personal account in the form of letters to and from D. H., Frieda, and Robinson Jeffers, a poet 
who had also been Mabel's guest in Taos ${ }^{19}$. Lorenzo in Taos was characterised by one of Frieda's biographers 'as a highly impressionistic, vaguely defamatory memoir written within a month of [D. H. Lawrence's] death'. ${ }^{20}$ Brett's Lawrence and Brett: A Friendship (1933) is also a personal account but written in the second person, addressed explicitly to D. H. Lawrence himself. According to a florid review by Henry Seidel Canby, Frieda's is the best of the books by the three women who 'burn with an intense flame of reminiscence' about D. H. Lawrence. According to this reviewer, Frieda's book was superior to the others because she limited herself to 'a touching, intimate, and revealing story of their relationship' full of interesting details that will be useful for the biographer, who will get to work on the definitive account when 'the women and his other intimates have poured out all their reminiscences. ${ }^{21}$

Twenty-three years later, Caitlin Thomas's Leftover Life to Kill was similarly read as a response - in this case to John Malcolm Brinnin's Dylan Thomas in America (1955) - but one that had fallen short of its aims. Poet, literary critic and biographer Brinnin (1916-1998) acted as agent for Dylan's American tours between 1950 and Dylan's death in 1953. Dylan Thomas in America is a memoir of Dylan's visits to America and includes a detailed account of the poet's death as observed by Brinnin. Reviewers felt that while Leftover was 'tender and even dignified ${ }^{22}$ at best, it did nothing to contradict Brinnin's depiction. ${ }^{23}$ At worst, by trying to 'tell all', it was thought to join Brinnin in rolling in 'spiritual excrement'. ${ }^{24}$ Several critics concluded that Caitlin's efforts had not created art but rather a 'personal - too personal reaction'; a 'clamour out of the depths'. ${ }^{25}$ Any literary passages in Caitlin's book were deemed most likely accidental, or a pale imitation of Dylan's style. ${ }^{26}$ But, some critics (both male and female) hoped, perhaps the writing process had proved therapeutic to a clearly distressed and tragic woman. ${ }^{27}$ 
Not everyone sneered at or denigrated the books, however. Philip O'Connor in The Encounter said, with some caveats, that Caitlin's writing was 'astonishingly good'. ${ }^{28}$ She was also praised for her direct recollections of Dylan, his personality, and her analysis of his motives: '[H]ere in his widow's book is a little bit of Dylan Thomas'. ${ }^{29}$ While Frieda's book was not generally treated as literary - despite later re-evaluations of her other memoirs, as well as her letters and fictions, as eloquent and impressive $\mathrm{e}^{30}-$ reviewers found much to praise, describing her account as direct, dignified (by which they meant no grudges or recriminations were aired) and affective ${ }^{31}$ : 'one of the most moving narratives of death on record. ${ }^{32}$ Two reviewers even accorded her the title of shrewd critic, ${ }^{33}$ noting that she was the only biographer 'besides John Strachey to give full weight to [D.H. Lawrence's] proletarian origin., 34

Following the interpretation of these texts as memoirs, or forms of intimate biography 'biography lite', if you will - of important writers, a scholarly rereading might offer insights into the relationship between gender and creativity, and the dynamics of literary couplings. ${ }^{35}$ In this article, I will ground my analysis of the transnational elements of Frieda's and Caitlin's accounts in the growing body of scholarship which has theorised women travellers' classed and gendered relationship with travel and travel writing.

\section{TRAVEL WRITING AND/AS LIFE-WRITING}

In her influential study of women's travel writing, Sara Mills outlines the many constraints upon how such works are received, not least the tendency to downplay the authority of the female voice ${ }^{36}$ amply demonstrated by the reviewers of Frieda's and Caitlin's works. She notes also that critics tend to praise writing that fits with their notions of femininity - as Frieda's seemingly modest and self-effacing work did, and Caitlin's did not - and to read 
everything women write as entirely autobiographical outpourings of emotion. These apparent characteristics - excessively personal, lacking authority, mere imitations of their husbands' style - were, as outlined in the previous section, all addressed in some form in the critical responses to Not I But the Wind... and Leftover Life to Kill.

Much like travel writers are themselves between one place and another, definitions of travel writing in academic literature often begin by pointing out the ways in which it is a peripatetic genre, ${ }^{37}$ a hybrid, as Mary Baine Campbell notes, 'composed of other genres' ${ }^{38}$ such as the essay, memoir, autobiography, travel journalism, maritime narratives, ethnography, or narrative of exotic escape. ${ }^{39}$ Travel writing chronicles or reconstructs, as Not I But the Wind... and Leftover Life to Kill do, the narrator's 'experience of displacement, encounter, and travail and his or her observations of the unknown, the foreign, the uncanny. ${ }^{40}$ As we also find in Frieda's and Caitlin's texts, travel writing is generally narrated in the first person by an author-traveller who refers to events that we are asked to believe really took place. ${ }^{41}$ Most often, we find that the narrative begins at home, and Frieda's and Caitlin's writings are no exception.

\section{ESCAPING HOME}

It is this 'stifling home', as Meaghan Morris observes, that is 'the place from which the voyage begins and to which, in the end, it returns. ${ }^{42}$ At the beginning of their narratives, when they are in Nottingham and Laugharne - the small town in Carmarthenshire where the Thomases lived at the time of Dylan's death - respectively, Frieda and Caitlin depict themselves at home, where they are sessile, 'permanently planted, tenaciously fixed, utterly immobile', a characteristic Sidonie Smith codes as feminine, drawing a contrast to the journey as a key component of masculine agency. ${ }^{43}$ 
Frieda writes that she appeared to have everything a woman could reasonably ask for, yet she is intellectually unfulfilled, 'living like a somnambulist in a conventional set life [...] all “smockravelled," 44 to use one of D. H. Lawrence's phrases'. Meeting D. H. Lawrence and deciding to elope Frieda characterises as a painful process of being 'born and reborn [...] into your own intrinsic self, that separates and singles you out from all the rest' ${ }^{45}$ Caitlin, recently bereaved and with very limited funds, was similarly befuddled; she describes herself as trapped in an unrewarding domestic life in which 'the simplest automatic task, like swabbing a table, is a major scientific problem [...] with all the slow wits chugging at the one and only method of perfecting swabbing and for what?' (p. 6). Neither Caitlin nor Frieda were domestically equipped. In an attempt to counter the criticism that was directed at Frieda by several D. H. Lawrence biographers, Rosie Jackson points to Frieda's privileged early years to argue that it was not '(mere) sloth that let Lawrence (willingly) do many of the household tasks: they were simply not part of her early repertoire'. ${ }^{46}$ With similar consequences for her domestic skills, Caitlin was raised in a bohemian environment in which she and her sisters were 'taught all the appurtenances of ladies, with none of the circumstances in which to practise them', which resulted in 'a very incongruous band of guerrilla ladies [...] blissfully unfitted, in every social and domestic respect, for the wifely rigours before us' (p. 106).

As well as absconding from a situation that did not fulfil them, Frieda and Caitlin positioned themselves as outsiders at home, breaching the protocols of proper femininity for women of the British middle class into which they had married. Frieda, the daughter of a Baron, left her respectable husband and children for a Nottinghamshire miner's son; Caitlin, from an old Irish landowning family and recently widowed, did not hide her indulgence in casual sex with local working-class men. ${ }^{47}$ Frieda did not seem to care much what others thought of her, writing in her memoirs that she did not think of herself as a social being, nor even really understand what society meant. ${ }^{48}$ Caitlin convinced her friends that she 'didn't 
care a bugger what anyone thought', ${ }^{49}$ but this impression is belied by her writing. For example, in her account of the way the people of Laugharne viewed her, to some extent before but certainly after Dylan's death, she felt 'castigated, reviled and morally spat on' especially by the local women, who would gleefully have tarred and feathered her, and 'with screams of ecstasy, set light to [her] in the market square' (p. 15). This was particularly galling to Caitlin as she felt she had given so much more of herself to the 'flat, sour, watery country' (p. 11) than Dylan had, so that being 'stoned out', as she described it, made her feel 'like the most unjustly abused martyr' (p. 16). On publication of Leftover, some critics appeared to share the townspeople's view that Caitlin cut 'an utterly hopeless figure' ${ }^{50}$ as a widow, not so much because of her sexual exploits, but because her 'romantic daydreams of glory and fame as the centre of attention ${ }^{51}$ were too egotistical: understandable in an artist and a man but abnormal for a woman and a mother. ${ }^{52}$ In Frieda's case, according to the norms that governed behaviour among her class in fin-de-siècle Germany, she had also made a shocking blunder - not in the fact of being unfaithful to her first husband, Ernest Weekley, but in getting caught. ${ }^{53}$

That is not to say that in escaping their old lives the two women did not bitterly regret some of what they left behind. All three of Frieda's children remained with her former husband as the law dictated; and while Caitlin took her youngest child with her, her two eldest remained in their English boarding schools. For Frieda, being required to leave her children meant that her journey began with 'hope and agony' and was a time when she was 'blind and blank with pain'. ${ }^{54}$ Her children were on Caitlin's conscience as well, giving her 'a knife-turning pain to think about'. However, thoughts of her children were 'indissoluble from Dylan, and, that other plague-shunned life, dripping with sodden associations and melting nostalgias' (p. 160). Nevertheless, they departed, Caitlin celebrating that she was on her 'way at last $[\ldots]$ vines, olives, and the extra- ordinary fact, that I am not treated as scum any more' 
(p. 17). Likewise, the Lawrences 'set out gaily [from Bavaria]. Neither of us knew Italy at the time, it was a great adventure for both. We packed up our few possessions, three trunks went ahead of us to the Lago di Garda' (pp. 41-42). As these quotations show, both women set forth on their transnational travels with some mixed feelings about what they were leaving behind, but with a sense of an exciting future ahead in a new country. Their respective arrivals, however, were to be as emotionally and practically complex as their departures.

\section{IMPRESSIONS}

'Whatever possessed me to think that a vague idealistic hunch, derived straight from my father's follies, would bring me sublime peace, and over the mountain fulfilment?' (p. 16), Caitlin wrote, reflecting upon her feelings, as she arrived in Rio Marina in Elba, which she described as 'the ugliest town on the island, scarred on the coast with Nature's red brown Gashes, from the steaming with chesty dust, iron mines' (p. 17). She was unimpressed with the facilities in her hotel, where there was 'not an apology of hot water or bath to be had' (p. 18). To make matters more confusing for Caitlin, she was put in 'La stessa camera, our old room' (p. 18), all the details of which she remembered from her last visit with Dylan. ${ }^{55}$ She had, in several senses, brought 'home' with her, despite her attempt to leave it behind in her pursuit of personal and creative agency.

Frida's observations on her arrival in Italy were similarly bleak. After an exciting walk over the Alps, during which she fulfilled her desire to sleep in a hayloft, she and D. H. Lawrence 'could only afford a very cheap hotel [in Trento] and the marks on the walls, the doubtful sheets, and worst of all the W.C.'s [sic]' caused her to weep in the way that the privations of the journey, which had 'seemed only fun' to her (p. 48), had not. This pattern of underwhelming arrivals in hotels is repeated in Mexico City, where the Lawrences' hotel 
'seemed dull and a bit unclean [...] Mexico City seemed like a would-be smart and grand lady to me, but she hadn't quite brought it off' (p. 122).

In this way, Frieda's and Caitlin's recorded experience demonstrates the contradiction identified in other studies of women's travel writing ${ }^{56}$ in which the liberated identity they have constructed as women who long to escape the stifling prison of middle-class England co-exists awkwardly with the bourgeois matron who expects fresh clean sheets and plentiful hot water on demand. Shirley Foster and Sara Mills have explored the ways in which the European domestic is foregrounded in women's travel writing, particularly in the nineteenth century. This they interpret as women travellers seeking to sustain their identity through comparison to the unfamiliarity of the 'Other'. ${ }^{57}$ Two examples in Frieda's text of encounters with the local populations in Tahiti and Mexico illustrate particularly clearly how such comparisons serve to reinforce Frieda's identity as a stylish, aristocratic European, her depictions of the people she meets particularly apparent in juxtaposition to her descriptions of the natural settings: the 'perfect weather' and 'flying fish, porpoises, sky, the great sea' are the 'perfection of the island' of Tahiti. But for Frieda, the joy is muted: the 'charming native women, who offered me old beads and flowers made me sad in their clumsy Mother Hubbard garments' (p. 118); and some young Tahitian film stars who travelled on the same boat to San Francisco

seemed to sleep all day and looked white and tired in the evening. Cases of empty champagne bottles stood outside their cabin in the morning. One of them I had seen flirt quite openly with a passenger but when we arrived in San Francisco I saw her trip so innocently into the arms of a young man who was waiting for her. (p. 118) 
The judgement on the young Tahitians' morals hinted at in this passage, allied to the assumption that the childlike and innocent exterior is merely for show, seems at odds with Frieda's comments elsewhere in the text on her belief "that if only sex were "free" the world would straightaway turn into a paradise' (p. 1). The second example is found in her censure of the boatmen in Mexico, and follows a similar pattern; while this is a place of 'sunshine and splendour of flowers and lots of birds and fruit and white volcano peaks' (p. 124), the people are savage and violent, as illustrated by an incident on the island of scorpions [sic], where 'Lawrence bought a live goat, but when we had seen our Mexican boatmen practically tearing the poor beast to pieces, our appetites vanished and we did not want to eat any more' (p. 124).

In the examples above, as well as in many of the texts analysed by Foster and Mills, ${ }^{58}$ the Other is of another culture, not European. In Caitlin's text, however, we find a contrast drawn between Northern European and Southern European, i.e. the Italian. Italy has long appealed to Northern European travellers such as Grand Tourists attracted by the cultural and archaeological remnants of ancient Mediterranean mobilities and the pleasant surroundings of the Italian Riviera and the Lakes. Women writing of Italy, as both Caitlin and Frieda did, may have drawn upon writers such as Lady Anna Riggs Miller, Hester Lynch Piozzi, ${ }^{59}$ and Mme de Staël; yet, there is no evidence that Frieda or Caitlin were directly influenced by these works. The Lawrences' first visit occurred just before the First World War resulted in a sharp decline in tourists, and the couple joined many others in returning to Italy throughout the 1920s. Caitlin's visit to Elba, and subsequently Procida and Rome, coincided with an increase in visitor numbers towards the mid-1950s as part of the post-war growth in tourism. ${ }^{60}$

Caitlin's comments on the people in Rio Marina bear similar assumptions of childish brutality to those Frieda made about Mexicans, as well as some of the hallmarks of anti- 
Italianism, a prejudice that grew among the British population during the Second World War and continued in the $1950 \mathrm{~s}:{ }^{61}$

$[\ldots]$ the undulating supremacy of their unthinking bodies, unchanging customs, and brutal taboos; and their callous lack of comprehension, or even desire to comprehend [...] As with a child, such egotism is sometimes winning; but there are complicating times when a coating of maturity, a picot edging of intellect are worth all the disarming children on earth. (p. 120)

As well as the egoism and coarseness she found in the people she encountered in Rio Marina, Caitlin saw no 'signs of intellectual activity whatsoever, not one positive book, no printed matter beyond a newspaper' (p. 150), though at least, she wrote, she could therefore be reassured that local people were not attempting to befriend her to benefit from Dylan's literary influence. On another occasion she was mildly amused when she and a number of locals sat down to watch an operetta on the television: 'There was a deafening roar, jags of child's lightning, darting crazily up and down'. Instead of turning off the set, the whole company sat through the production in solemn silence, 'merely remarking at the end that the reception was not very good owing to atmospheric disturbances' (p. 95).

These themes of innocence and harshness also prevail in both Frieda's and Caitlin's descriptions of Italian landscapes. Of Frieda's 'wonderful mornings' by the Mediterranean, when she would walk through the groves to collect the post, she writes that it took time to 'see the beauty of these olive trees, so different at different times; the wind running up them turns them into quicksilver' (p. 63). Caitlin goes further, exhorting the landscape to consume 
her with its 'sharp teeth of bushes, brambles, baiting briars', and comparing the scenery to a 'Christ in the Wilderness setting' (p 161). Equally, Frieda 'wouldn't have been surprised meeting Christ and his disciples - it may be just as well that I didn't' (p. 63). It is not clear what temptations, if any, Frieda might see herself as resisting, or indeed joyfully failing to resist; but for Caitlin there is the repeated pattern of resisting belonging while despising her own longing to be seen and accepted. In her wilderness, 'everything was there except the Christ; as I sat on a flat stone, eating bare bread and drinking the mountain moss-sweet water, from cupped hands; that I felt less despoiled, but very rarely serene' (p. 161). One way to interpret this difference could be that Frieda travels through these landscapes with the emotional, social and physical security represented by a husband, whereas Caitlin is a woman alone. However, both Frieda and Caitlin, regardless of their feelings of confidence or vulnerability in the landscape, draw upon similar literary techniques to set the scenes in their autobiographical writing.

\section{VIEWPOINTS}

The various passages setting the scene of a new place, or describing encounters with new people, might appear, at first reading, to stand in stark contrast to Mary Louise Pratt's identification of the 'Imperial Eye' ${ }^{62}$ in much travel writing from the 1800 s to the twentieth century. But Caitlin's and Frieda's descriptions are performing a similar function: they are integrating their impressions of these unfamiliar places and people into familiar discourses. In place of Pratt's masculine colonising hero, however, in these texts we discover a particular gendered and classed positioning of the narrator. For example, it is noticeable how frequently both Frieda and Caitlin set their scenes from the viewpoint of a window. In contrast to the traditional masculine promontory view identified by Pratt, where the surveying eye is a 
highly visible and dominating presence, a window not only shields the observer from view but locates her, once again, in a domestic space.

When Frieda first meets D. H. Lawrence, she is watching her children playing through French windows, the 'curtains fluttering in the spring wind'; and this is the moment he informs her that he has 'finished with his attempts at knowing women' (p. 2). In their first villa at Gargnano, their windows look 'over the lake, the road running underneath, opposite us the Monte Baldo in rosy sunsets' (p. 49). ${ }^{63}$ This view was a joy to Frieda - 'Bersaglieri came past in their running march [...] people did their bargaining under my windows, at night the youths played their guitars' (pp. 49-50) - but D. H. Lawrence was 'cross' with her when she peeped out at these goings on. Frieda does not explain why her husband would behave this way, though at the time he was rewriting Sons and Lovers and asking her to 'go deeply into the character of Miriam' (p. 50), based upon D.H. Lawrence's childhood sweetheart, Jessie Chambers. ${ }^{64}$ For Caitlin as well, there were pains and pleasures to be had in experiencing Rio from 'window gazing, from inwards, downwards, not outward' (p. 39), which included sights, "performers on the street below conscious of their audience, excel[ling] themselves in the fervour of their buying and selling'; and sounds, like church bells and the 'rising cackle of the market' that were 'as lullabying as the gentle lapping of waves; and the hotel is not even on the sea' (p. 18).

On occasion, however, the window reveals, or symbolises, an unsettling view. In Sydney, Frieda watched a storm throwing waves that 'rose on the abrupt shore, high as in an enormous window.' In the waves she saw strange creatures, 'sword-fish and fantastic phenomena of undreamt deep-sea beasts [...] frightening and never to be forgotten' (p. 106). With Caitlin, once again a middle-class matronly distaste for the domestic standards of the Other (or their perceived lack) is present in her observations of the 'rubbed-to-the-skeleton, 
family wash' (p. 129) that could always be seen blowing from the windows, and the practices of the waste collectors, who

drove the heaped-up load to the edge of the cliff, tipped it carelessly half over, in a high wind, and the whole lot promptly blew back into the town. Soiled papers and rags flew up to the ever open, grandstand windows, with women, and lines of washing, permanently fluttering out of them. (p. 38)

In both Caitlin's and Frieda's writing, the windows tend to be open or, if not open, they have the potential to be opened. They do not represent a prison, such as the barred windows in Charlotte Perkins Gilman's classic, The Yellow Wallpaper; rather they are like a portal or,

more active still, an eye. ${ }^{65}$ But while these windows are open, also on a symbolic level, they do act as a boundary between the woman inside and the life of the Other that is taking place outside; a barrier that allows Caitlin and Frieda to remain in the shadows, to look without being seen, to listen without being heard. The window can also be perceived as a frame and the scene beyond a painted landscape, lending it a sense of unreality. In these ways, the positioning of the narrator as behind a window continues this tangled relationship between the positions of watcher and watched.

\section{BEING WATCHED}

Despite the protection of the window, however, Frieda and Caitlin were still unable to cast off neither the watchful eyes that followed them, nor the tongues that whispered in their 
wake. Frieda's difficulties, as related in Not I But the Wind..., were related primarily to her nationality at certain historical moments. I have already outlined her sense of discomfort as a German child living in a territory that had recently been ceded from France to the German Empire, but in 1914 the war came 'out of the blue' (p. 68) for the Lawrences, who were at the time holidaying in England after their wedding, and it was a source of helpless despair.

In London one evening, Frieda describes spotting a Zeppelin hanging over Hampstead Heath; she realises that if the crowd knew she was German they would 'tear [her] to pieces in their fear' (p. 69). She felt surrounded by suspicion and panic, 'like breathing bad air' (p. 75), and recounts several incidents during which she and her husband were stopped, searched and asked for papers; she also recalls occasions when they policed their own behaviour in the knowledge of how it might appear to others. The Lawrences' washing line was once suspected of being a method to signal to German submarines, and Frieda was accused of taking photographs near the coast, which was illegal at the time under the Defence of the Realm Act (the object assumed to be a camera was, in fact, a loaf of bread; pp. 76-77).

It could not have helped matters that Frieda was distantly related to the 'Red Baron', Manfred von Richthofen. ${ }^{66}$ In Not I But the Wind... she recalls an incident by the sea in Cornwall, when she was 'intoxicated by the air and sun. I had to jump and run, and my white scarf blew in the wind. "Stop it, stop it, you fool, you fool!” D. H. Lawrence cried. “Can't you see they'll think that you're signalling to the enemy!"' (p. 75). Like Caitlin, Frieda was contemptuous of those who watched and who, on this occasion, had presented themselves to accuse the Lawrences' host - the couple were staying with composer and music critic Cecil Gray (1895-1951) at Bosigran Castle ${ }^{67}$ - of having a light in his window that could be seen at sea. Frieda was pleased that the policemen 'were all covered with mud, having fallen into a ditch listening under the windows' (p. 77). However, the Lawrences were far from unique in the mistrust they experienced during the war; thousands of bohemians and artists - English as 
well as other nationalities - faced similar suspicion from members of the public and the authorities. ${ }^{68}$

An especially galling aspect of the scrutiny Caitlin faced was the hypocrisy she perceived in her treatment. The kinds of things 'they' whispered embodied, in her opinion, the 'worst instincts of the community; of petty persecution' (p. 8). By this she means that she perceived herself as the victim of spiteful gossip in Wales, as outlined earlier, and in Rio alike, not because she flouted conventions, but because she acted openly while 'they' did so in hiding. When her landlord at the hotel in Rio Marina - whom she called 'The Church' and with whom she was having a sexual relationship - chastises her for continuing to meet her other

lover, Joseph, Caitlin is incensed that he 'got so wild over my slight detractions from his holy conventional code; which nevertheless, did not stop him from betraying his sacred wife [...] it was the old, old story, not of right and wrong, but of what is seen and not seen' (p. 85). These tensions between the ways in which the two writers describe their observations of others and the emotions they portray in their own responses to being watched speak, once again, to the dualities they are attempting to navigate. Dualities that include their transnational, classed, and - particularly in the case of watching and being watched - their gendered identities, even as they attempt to throw them off.

\section{CONCLUSION}

While Frieda's and Caitlin's texts meet the definitions of travel writing outlined in the scholarly literature on the subject, as I summarised earlier in the article, neither is a straightforward travel book. These books are written in a confessional style by relatively inexperienced writers, in a context of much speculation, at a time of heightened emotion following the death of a husband. These factors, along with Frieda and Caitlin's hope to tell 
their own stories as they wanted them told, render the women especially vulnerable. The books might represent, one might even be tempted to suggest, an attempt to 'come of age' as independent women writers liberated, in their particular gendered and historical context, from the influence of their respective famous husbands. Indeed, while Caitlin and Frieda seem to think of travel as incidental, a means to an end to the main themes they want to address, (to give an account of themselves in their own words) there is a long association in fiction between travel and the bildungsroman, an association Yolanda Doub calls 'road trips and coming-of-age stories'. ${ }^{69}$

However, it seems that much of what Caitlin and Frieda hoped to escape by travelling to another place they bring with them, wrestling with the gendered and classed norms they intended to cast off and offering particularly localised and historicised interpretation of what they see and experience that sites its divisions between the Northern European and the Other. And that Other, whether Italian, Tahitian, or Mexican, is characterised by savagery and uncultured barbarianism. In this way, as with our understanding of travel writing as a peripatetic genre, these hybrid texts can be read, much as a transnational life can be read, as occupying a liminal space. As the authors construct an identity that is not quite British, not quite German, not quite Irish; not quite sessile not quite free; not quite watcher not quite watched; not quite 'writers', certainly in the eyes of critics, in comparison to their husbands.

Acknowledgements: This research was supported by a bursary from the Oxford Dictionary of National Biography. Sincere thanks to Sandra Mayer and Clément Dessy for their insightful comments on an earlier draft of this article. 
${ }^{1}$ For the purposes of this article I have elected to refer to Frieda Lawrence, Caitlin Thomas and their respective spouses by their given names.

2 Desley Deacon, Penny Russell and Angela Woollacott, 'Introduction', in Transnational Lives: Biographies of Global Modernity, 1700-present, edited by Desley Deacon, Penny Russell and Angela Woollacott (London: Palgrave Macmillan, 2010), pp. 1-14 (p. 2).

3 Janet Byrne, A Genius for Living: The Life of Frieda Lawrence (London: Harper Collins, 1995), p. 27.

${ }^{4}$ Nicolette Devas, Two Flamboyant Fathers (New York: Morrow, 1967), p. 21.

${ }^{5}$ In Double Drink Story: My Life with Dylan Thomas (London: Virago, 1998), Caitlin refers to herself as an 'Irish lass' (p. 6), possessed of 'Irish false pride' and 'Irish fear' (p. 18). But she also distances herself from her Irish background: from 'them' and 'their impulsive rush from the bogs of Ireland to the streets paved with gold of America: from peasant to glorified peasant, but always pre-eminently peasant.' (Caitlin Thomas, Leftover life to kill, London: Putnam, 1957, p. 151).

${ }^{6}$ See Devas, Two Flamboyant Fathers, pp. 37-49.

${ }^{7}$ Byrne, A Genius for Living, p. 28.

${ }^{8}$ For a full list of Frieda Lawrence's publications, see Byrne, A Genius for Living, pp. 471472.

${ }^{9}$ See 'Timeline: European Reception of W.B. Yeats', in Klaus Peter Jochum (ed.) The

Reception of W. B. Yeats in Europe (London: Bloomsbury, 2006), p. xxi.

${ }^{10}$ Paul Ferris, 'Thomas [née Macnamara], Caitlin (1913-1994)', Oxford Dictionary of

National Biography (4 October 2012), < https://doi.org/10.1093/ref:odnb/55871> [accessed 1 August 2019].

${ }^{11}$ Ferris, Oxford Dictionary of National Biography.

${ }^{12}$ Ferris, Oxford Dictionary of National Biography.

${ }^{13}$ She stayed there between October 1954 and March 1955. See Paul Ferris, Caitlin: The Life of Caitlin Thomas (London: Random House, 1995), pp. 160 and 168.

${ }^{14}$ This is from Dylan's poem, I make this in a warring absence: 'I make this in a warring absence when / Each ancient, stone-necked minute of love's season / Harbours my anchored tongue.' First published in The Map of Love, 1939. See Dylan Thomas, Collected Poems 1934 - 1953, edited by Walford Davies and Ralph Maud (London: Phoenix, 2003), p. 68.

${ }^{15}$ Caitlin Thomas, with George Tremlett, Caitlin: A Warring Absence (New York: Henry Holt and Company, 1986), p. viii.

16 Thomas, Double Drink Story, pp. xiii-xiv.

${ }^{17}$ Quotation from 'Not I But the Wind by Frieda Lawrence, Release date: OCT. 8, 1934', Kirkus Reviews Issue: Oct. 1, $1934<\mathrm{https}$ //www.kirkusreviews.com/book-reviews/a/friedalawrence/not-i-but-the-wind/ > online] [accessed 27 August 2019].

${ }^{18}$ Dorothy Brett, Lawrence and Brett: A Friendship (Santa Fe: Sunstone Press, 2006), epilogue, pp. x-xi.

${ }^{19}$ Mabel wrote to D.H. Lawrence in 1921 to invite him to her farm in Taos, the Lawrences arrived there in September 1922. See Brenda Maddox, D.H. Lawrence: the Story of a Marriage, (London: Simon \& Schuster, 1994) p. 311.

${ }^{20}$ Byrne, A Genius for Living, p. 346.

${ }^{21}$ Henry Seidel Canby, 'On Living With a Genius: "Not I, But the Wind...”, by Frieda Lawrence', The Saturday Review, 13 October 1934, p. 203.

${ }^{22}$ Isabel Quigly, 'Child in the Dark', Spectator, 7 June 1957, p. 22.

${ }^{23}$ Katherine Anne Porter, 'In the Depths of Grief, a Towering Rage', New York Times Book Review, 13 October 1957, p. 3. 
${ }^{24}$ M. L. Rosenthal, 'Caitlin Thomas in Capri [sic] Leftover Life to Kill, by Caitlin Thomas', The Nation, 2 November 1957, p. 308.

${ }^{25}$ Quigly, 'Child in the Dark', p. 22; Porter, 'In the Depths of Grief', p. 3.

${ }^{26}$ See Quigly, 'Child in the Dark', p. 22; Rosenthal, 'Caitlin Thomas in Capri', p. 308;

Robert Graves, 'And the Children's Teeth are Set on Edge', The New Republic, October 28 1957, p. 17.

${ }^{27}$ See Porter, 'In the Depths of Grief', p. 3; Rosenthal, 'Caitlin Thomas in Capri', p. 308.

${ }^{28}$ Philip O’Connor, 'Books In Brief: Leftover Life to Kill, by Caitlin Thomas', Encounter, August 1957, pp. 87.

${ }^{29}$ William Bittner, 'A Little Bit of Dylan Thomas: Leftover Life to Kill, by Caitlin Thomas', The Saturday Review, 12 October 1957, p. 22.

${ }^{30}$ Rosie Jackson, Frieda Lawrence: Including Not I, But the Wind and Other Autobiographical Writings (Sheffield: Pandora, 1994), p. 6.

${ }^{31}$ Ferner Nuhn, "Not I, But the Wind...”, by Frieda Lawrence', The Nation, 24 October 1934, p. 483.

${ }^{32}$ Philip Stevenson, 'Postscript', The New Republic, October 24 1934, p. 316.

${ }^{33}$ Kyle Crichton Scribners, "Not I, But the Wind...", by Frieda Lawrence', Holiday Book Supplement D.H. Lawrence, December 1934, p. 17.

${ }^{34}$ Stevenson, 1934, p. 316.

${ }^{35}$ See Jackson, Frieda Lawrence. For other examples, see Heather Clark, The Grief of Influence: Sylvia Plath and Ted Hughes (Oxford: Oxford University Press, 2010); Whitney Chadwick and Isabelle de Courtivron, Significant Others: Creativity \& Intimate Partnership (London: Thames \& Hudson, 2018).

${ }^{36}$ Sara Mills, Discourses of Difference: An Analysis of Women's Travel Writing and Colonialism (London: Routledge, 2003).

${ }^{37}$ Charles Forsdick, 'De la plume comme des pieds: the Essay as Peripatetic Genre', in The Modern Essay in French: Movement, Instability, Performance, edited by Charles Forsdick and Andrew Stafford (Oxford: Peter Lang, 2005), pp. 45-60. See from p. 57 for a discussion of travel writing as a peripatetic genre.

${ }^{38}$ Mary Baine Campbell, The Witness and the Other World: Exotic European Travel Writing, 1400-1600 (Ithaca: Cornell University Press, 1991), p. 6.

${ }^{39}$ See Patrick Holland and Graham Huggan, Tourists with Typewriters (Michigan: University of Michigan Press, 1998); Michael Kowalewski, ed., Temperamental Journeys: Essays on the Modern Literature of Travel (Athens: University of Georgia Press, 1992); Barbara Korte, English Travel Writing from Pilgrimages to Postcolonial Explorations (New York: St. Martin's Press, 2000); Peter Hulme and Tim Youngs, eds, The Cambridge Companion to Travel Writing (Cambridge: Cambridge University Press, 2002); Tim Youngs, The Cambridge Introduction to Travel Writing (Cambridge: Cambridge University Press, 2013); Sidonie Smith and Julia Watson, Reading Autobiography (Minneapolis: University of Minnesota Press, 2010).

${ }^{40}$ Smith and Watson, Reading Autobiography, pp. 284-285.

${ }^{41}$ Chu-Chueh Cheng, 'Frances Trollope's America and Anna Leonowens's Siam: Questionable Travel and Problematic Writing', in Gender, Genre, and Identity in Women's Travel Writing, edited by Kristi Siegel (Oxford: Peter Lang, 2004), pp. 123-166.

${ }^{42}$ Meaghan Morris, 'At the Henry Parkes Motel', Cultural Studies, 2 (1988), 3-25 (p. 12).

${ }^{43}$ Sidonie Smith, Moving Lives: Twentieth Century Women's Travel Writing (Minneapolis: University of Minnesota Press, 2001), p. 1.

44 'Smock-ravelled' means puzzled or perplexed. See David. E Gerard, 'Glossary of Eastwood dialect words used by D. H. Lawrence in his poems, plays and fiction', The D. H. Lawrence Review, 1.3 (1968), 215-237 (p. 233). The term appears in Lawrence's dialect 
poem 'Whether or Not' and in a letter to Henry Savage, 15 September 1913. For the latter, see D. H. Lawrence, The Letters of D. H. Lawrence Volume II, edited by George J. Zytaruk and James T. Boulton (Cambridge: Cambridge University Press, 1981), p. 74.

${ }^{45}$ Caitlin Thomas, Leftover life to kill. (London: Putnam, 1957), p. 1. All references to Leftover from here onwards will be indicated with the page number only.

${ }^{46}$ Jackson, Frieda Lawrence, p. 74.

${ }^{47}$ Caitlin herself makes oblique reference to this behaviour in Leftover: 'I sought filthily to purge the blood-thronging devils out of me by using the devil's own filthier-still instruments. I stole their sons and husbands, doing violence to both our diversely raw feelings; violating purposefully my most precious holy vows to Dylan' (p. 15).

${ }^{48}$ Jackson, Frieda Lawrence, p. 74, footnote 85, referencing Frieda's memoirs.

${ }^{49}$ Vera Philips, a childhood friend of Dylan from Swansea, told biographer Paul Ferris that Dylan 'was brought up like me, worrying "What will the neighbours think?" Whereas Caitlin didn't care a bugger what anyone thought'. Ferris, Caitlin, p. 164.

${ }^{50}$ Rosenthal, 'Caitlin Thomas in Capri', p. 308.

${ }^{51}$ Porter, 1957, p. 3.

${ }^{52}$ Quigly, 'Child in the Dark'.

${ }^{53}$ Byrne, A Genius for Living, p. 105.

${ }^{54}$ Quoted in Jackson, Frieda Lawrence, p. 54.

${ }^{55}$ See Andrew Lycett, Dylan Thomas: A New Life (London: Phoenix, 2003), p. 286.

${ }^{56}$ See Smith, Moving Lives; Mills, Discourses of Difference; Frances Bartkowski, Travelers, Immigrants, Inmates: Essays in Estrangement (Minneapolis: University of Minnesota Press, 1995).

${ }^{57}$ Shirley Foster and Sara Mills, eds, An Anthology of Women's Travel Writing (Manchester: Manchester University Press, 2002), p. 9.

${ }^{58}$ See Foster and Mills's introduction to their 'Women writing other women' section, pp. 1418.

${ }^{59}$ See Mirella Agorni, Translating Italy for the Eighteenth Century: British Women, Translation and Travel Writing (1739-1797) (London: Routledge, 2014).

${ }^{60}$ See Ruth Ben-Ghiat and Stephanie Malia Hom, eds, Italian Mobilities (Abingdon:

Routledge, 2016) and Sandro Formica and Muzaffer Uysal, 'The Revitalization of Italy as a Tourist Destination', Tourism Management, 17.5 (1996), 323-331, (pp. 327-328).

${ }^{61}$ Terri Colpi, The Italian Factor. The Italian Community in Great Britain (Edinburgh: Mainstream Publishing Company, 1991).

${ }^{62}$ Mary Louise Pratt, Imperial eyes: Travel writing and transculturation (London: Routledge, 1992), in particular Chapter 9, from p. 201.

${ }^{63}$ In Not I But The Wind... Frieda claims that the line in Lawrence's poem 'Winter Dawn', 'Green star Sirius dribbling over the lake', reminds her of this view (p. 49).

${ }^{64}$ For a review of Jessie Chambers's and Frieda Lawrence's involvement with Sons and Lovers and Miriam, see Neil Roberts, 'Jessie Chambers, Frieda Lawrence and the Rewriting of "Sons and Lovers"', The D.H. Lawrence Review (2016), 41:1.

${ }^{65}$ See Ellen Eve Frank, Literary Architecture: Essays Toward a Tradition: Walter Pater, Gerard Manley Hopkins, Marcel Proust, Henry James (Berkeley: University of California Press, 1983).

${ }^{66}$ MSS. 0621., 1924-1958, (University Libraries Division of Special Collections, The University of Alabama)

${ }^{67}$ D. H. Lawrence, The Letters of D. H. Lawrence Volume VIII, edited by James T. Boulton (Cambridge: Cambridge University Press, 2000), p. 25.

68 James Fox, British Art and the First World War, 1914-1924 (Cambridge: Cambridge University Press, 2015), p. 50. 
${ }^{69}$ Yolanda A. Doub, Journeys of Formation: The Spanish American Bildungsroman (Oxford: Peter Lang, 2010), p. 1. 